\title{
The genus Rhaponticum in East Asia
}

\author{
A. VOROBYEVA ${ }^{1} \&$ P. GOROVOY ${ }^{2}$ \\ ${ }^{1}$ Laboratory of Plant Introduction, Amur Branch of Botanical Garden-Institute, Far-East Division, Russian Academy \\ of Sciences, Ignatievskaya line km 2, 675004 Blagoveschensk, Russia \\ ${ }^{2}$ Laboratory of Plant Chemotaxonomy, Pacific Institute of Bioorganic Chemistry, Far-East Division, Russian \\ Academy of Sciences, 100-letiya Vladivostoky Ave. 159, 690022 Vladivostok, Russia \\ Author for correspondence: A. Vorobyeva (sparrowaj@mail.ru)
}

Received 19 May 2009; Accepted 30 June 2010

\begin{abstract}
The genus Rhaponticum in East Asia has always been a taxon for discussion. Rhaponticum carthamoides from East Siberia comprises three subspecies: carthamoides, chamarensis and orientale. Even though they differ in morphology, they do not have isolated areas. Rhaponticum satzyperovii was recently described and its author pointed out its affinity with $R h$. uniflorum. Plant height, stem indumentum, and radical and stem leaf dissection were signaled as the diagnostic characters. Our present study on living and herbarium specimens of $R h$. satzyperovii shows that the diagnostic characters are not consistent. The species area was also claimed to be an argument for considering $R h$. satzyperovii a distinct species. This area covers the south of the Primorye Province in the Far East of Russia with some locations in the adjacent Jewish Autonomous Region and in China. In our study, the area of Rh. satzyperovii is found to be within the area of $R h$. uniflorum and thereafter they turned out to have no disjunction. In East Asia, $R h$. uniflorum is characterized by a wide range of morphological variability. We suggest that Rh. satzyperovii should be included within Rh. uniflorum without any taxonomic rank.
\end{abstract}

Key words: East Asia; Rhaponticum; taxonomy.

\section{Resumen}

El género Rhaponticum en el Este de Asia.- El género Rhaponticum en el Este de Asia ha sido siempre un taxón discutido. Rhaponticum carthamoides del Este de Siberia incluye tres subespecies: carthamoides, chamarensis y orientale. Aunque difieren en su morfología, sus áreas no están aisladas. Rhaponticum satzyperovii fue descrito recientemente y su autor señaló su afinidad con Rh. uniflorum. Los caracteres diagnósticos fueron la altura de la planta, el indumento del tallo y las divisiones de las hojas basales y caulinares. Nuestro estudio de plantas vivas y muestras de herbario de Rh. satzyperovii muestra que los caracteres diagnósticos no son consistentes. El área de distribución también se argumentó para considerar Rh. satzyperovii una especie diferente. El área cubre el sur de la provincia de Primorye en el extremo Este de Russia con algunas localidades en la adyacente región Autónoma Judía y en China. En nuestro estudio hemos visto que el área de $R h$. satzyperovii está dentro del área de $R h$. uniflorum y por lo tanto no cabe hablar de disyunción. En el Este de Asia, Rh. uniflorum se caracteriza por un amplio rango de variabilidad morfológica. Proponemos que Rh. satzyperovii se incluya en Rh. uniflorum sin ningún rango taxonómico.

Palabras clave: Este de Asia; Rhaponticum; taxonomy. 


\section{INTRODUCTION}

Up to the present, the names Rhaponticum Vaill., Stemmacantha Cass. and Leuzea DC. have been used in floristic reports and in literature covering the studies on chemical composition of the plant species of Rhaponticum. The authorship of the name Rhaponticum was usually ascribed to Adanson (1763) and more recently to Vaillant (1718) according to Susanna and Garcia-Jacas (2007). However, this name was used as early as Bock, Prosperus, Bauhin and other authors (Dittrich, 1973; Holub, 1973, 1974).

Many taxonomists developed the system of the genus Rhaponticum. In 1718 Vaillant used this name for a group of plants including species of the genera Leuzea and Acroptilon Cass., according to the contemporary conceptions. In 1742, Haller used the name Rhaponticum (Holub, 1973) for the association of four species of the Asteraceae. Ludwig (1747) published the genus name Rhaponticum and included 9 species into the genus. Linnaeus (1753) developed the classification of Rhaponticum, but he placed many species of Centaurea L. into this genus. Lamarck (1779) excluded $C$. rhapontica L. from Centaurea and transferred to the genus Rhaponticum as Rh. scariosum Lam. Later on, a number of authors clarified and changed the boundaries of the genus Rhaponticum (Jussieu, 1789; De Candolle, 1838; Ledebour, 1845; Bentham, 1876; Hoffmann, 1890). They even placed species of the genera Cnicus L., Serratula L., Cirsium Mill. and Centaurea into this genus. The genus name Rhapontica was suggested by Hill (1762) and the IAPT (International Association of Plant Taxonomy) resolved to consider this name to be homonym of Rhaponticum (Dittrich, 1984), which led to the generalized use of the genus name Stemmacantha Cass., described by Cassini (1818) with Serratula cynaroides DC. as the type species. Cassini (1818) considered the special structure of calyx bracts to be the distinguishing character of the genus. The classification of Stemmacantha proposed by Dittrich (1984) was adopted by Czerepanov (1995) and it included 20 species, 10 subspecies and 2 varieties. Finally, Greuter (2003) recovered Vaillant's names and assigned, hopefully this time definitely, the name Rhaponticum to the genus. ${ }^{1}$

In the literature on flora of Siberia, the Russian Far East (RFE), Mongolia, Korea and China and in publications on taxonomy of the Asteraceae, there is no agreement regarding the species composition of the genus Rhaponticum. In the check-list of Czerepanov (1995) there are three species of Rhaponticum (as Stemmacantha), namely St. carthamoides (Willd.) Dittrich, St. uniflora (L.) Dittrich and St. satzyperovii (Sosk.) Czer. reported for East Asia.

Rhaponticum satzyperovii was described in 1959 by Soskov based on the collections of 1913 from Primorsky Province. Dittrich (1984) included it into Stemmacantha as a subspecies, St. uniflora subsp. satzyperovii (Sosk.) Dittrich.

Rhaponticum carthamoides (Willd.) Iljin is distributed on subalpine meadows of Central and East Siberia, and outside Russia it grows only in two locations in the Mongolian Altai (Grubov, 1982; Zhirova, 1997; Doronkin, 2003) and is represented by three subspecies: Rhaponticum carthamoides subsp. carthamoides, Rh. carthamoides subsp. orientale (Serg.) Doronkin, and Rh. carthamoides subsp. chamarensis (Peschkova) Doronkin, that differ in morphological characters (shape of appendages of outer involucral leaflets), but do not have isolated areas. There are no other species related to $R h$. carthamoides described from Siberia. In the south-eastern part of Siberia the area of $R h$. carthamoides reaches the area of the southern lakeside of Baikal (Zhirova, 1997).

Rhaponticum carthamoides is used in Russia as a medicinal plant and as a source for ecdysteroid production. Mass harvesting of these species today accounts for working out measures on its conservation. The cited literature and synonyms are provided below.

Rhaponticum uniflorum (L.) DC. was reported in «Key-book of plants of Primorye and Primurye» by Vorobyev et al. (1966), who listed Rh. satzyperovii as a synonym. To the contrary, Voroschilov (1966) reported two species of Rhaponticum for the RFE, Rh. uniflorum and Rh. satzyperovii, and noted that in the territory of Primorye Province there are plants both similar to typical Rh. uniflorum and others with

\footnotetext{
${ }^{1}$ Note added in press: According to Brummitt (pers. comm.), German translation of Vaillant on which relied Greuter's validation of the name Rhaponticum Vaill. will be declared opera utique oppressa by the Nomenclature Committee. The name for the genus returns to Stemmacantha Cass.
} 
characters transitional between $R h$. satzyperovii and Rh. uniflorum. Later on, Voroschilov $(1982,1985)$ combined $R h$. satzyperovii as $R h$. uniflorum subsp. satzyperovii (Soskov) Vorosch.

In the survey «Vascular plants of the Soviet Far East», Barkalov (1992) recognized two independent species: Rh. uniflorum and Rh. satzyperovii.

In the floristic surveys on Siberia by Popov (1959), Peshkova (1979) and Zhirova (1997), two species were reported for the territory of East Asia, $R h$. carthamoides and Rh. uniflorum. The «Key-book on vascular plants of Mongolia» the only accepted species was Leuzea uniflora (L.) Holub (Grubov, 1982).

Kitagawa (1979) reported Rh. uniflorum for Siberia, Mongolia, Amursky and Ussuriysky Regions, Korea and China. In the surveys on flora of Korea (Lee, 1993; Lee, 1996) only Rh. uniflorum was mentioned as well. Stemmacantha carthamoides and $S$. uniflora were reported for China (Chu, 1987), but $R h$. satzyperovii was treated as synonym of $R h$. uniflorum.

We carried out a study in order to ascertain whether $R h$. satzyperovii is a different species from Rh. uniflorum.

\section{MATERIALS AND METHODS}

The paper is based on the study of living plants of $R h$. uniflorum and Rh. satzyperovii collected during expeditions to nature populations in the Irkutskaya, Chitinskaya, Amurskaya and Jewish Autonomous Regions, Khabarovsky and Primorsky Provinces, and the study herbarium material in LE, MHA, MW, VLA, the Pacific Institute of Bioorganic Chemistry (Vladivostok), the Far-Eastern Branch of the Russian Academy of Sciences (FEB RAS), the Botanic Garden-Institute FEB RAS (Vladivostok), the Institute of aquatic and ecological problems FEB RAS (Khabarovsk), the Institute of Complex Analysis of Regional Problems FEB RAS (Birobidzhan), the Zabaikalsky State Pedagogical University of N.G. Chernyshevsky (Chita), the Blagoveschensk State Pedagogical University of M. I. Kalinin (Blagoveschensk), and literature data.

\section{RESULTS AND DISCUSSION}

Our study of living plants of Rh. satzyperovii, as well as observation of herbarium materials, has shown that the diagnostic characters indicated by
Soskov $(1959,1963)$ are not consistent. The species description (Soskov, 1959, 1963) details that $R h$. satzyperovii is close to $R h$. uniflorum, but «... it has isolated area and is well distinguished by its robust stem up to $1 \mathrm{~m}$ high, lyrate radical leaves and large superficially partite, often pinnatilobate, stem leaves and a number of other characters...». Having observed more than 300 plants of Rh. satzyperovii in "locus classicus" we were able to collect some specimens that corresponded to $R h$. uniflorum in their morphological characters.

We registered high variability in plants of both species. The most variable are the shape and dissection of radical and lower stem leaves, i.e. the characters that were considered to be distinguishing in the description of Rh. satzyperovii. Within a single population of $R h$. satzyperovii there are plants with lyrate radical leaves with a large terminal lobe and slightly partite lobed stem leaves, as well as individuals with pinnatipartite or pinnatifid leaf blades without a large terminal lobe. Often in the same leaf rosette there are leaves of two forms with all transitions between them. Such pattern is typical to both $R h$. satzyperovii from "locus classicus" and the plants in the northernmost location of the area (by Soskov YU.D.) of Rh. satzyperovii in the Jewish Autonomous Region in the vicinities of Bidzhan Settlement. Such pattern in leaf variability is observed in plants of Rh. uniflorum. The species characters that describe $R h$. satzyperovii easily fit into character variability of $R h$. uniflorum. We have not found any differences between $R h$. uniflorum and $R h$. satzyperovii in morphological characters.

Within the species one can find plants with xeromorphic pattern: dwarfish, with small dissected (often as deep as to the central costa) leaf blades with up to 12 pairs of narrow-lanceolate lobes. Usually those are plants which grow in open southern steppe or stony hill slopes. Xeromesophytic plants are tall (up to $1 \mathrm{~m}$ high), with large, pinnatilobate or slightly partite into 3-8 pairs of wide ovate-oblong lobes, lyrate leaves - they often occur on elevated sites river valleys, sea shores, sometimes under forest canopy. Plants with xeromorphous pattern grow in the north-western part of the area in the regions with continental, arid climate (the Tuva and Buryatiya Republics, the Irkutskaya, Chitinskaya and the north of Amurskaya Regions, Mongolia, North and Central China). Plants with xeromesophytic pattern are restricted to the regions with 
humid, warm, monsoon climate (the southern areas of the Amurskaya Region, the Jewish Autonomous Region, Primorsky Province, North-East China and Korea Peninsula).

The area of Rh. satzyperovii (Soskov, 1959) covers the territory of south Primorsky Province of the RFE, the Jewish Autonomous Region (Stolbovoye Village and Bidzhan Settlement) and North-East China (near Sochintsy, Matsyaokhe Station). In the area of Rh. uniflorum, Soskov (1963) reports a significant disjunction from the northern part of Zeya-Bureya floristic region (in the Amurskaya Reion) and «....as a carried plant on the MuraviovAmursky Peninsula, Putyatin Island and in the vicinities of Ussuriysk city ...».

While specifying the growth locations of $R h$. uniflorum in Russia, Mongolia, China and Korea we ascertained that this plant does not occur in the Russian Far East and Siberia as a carried plant and the area of the species turned out to be continuous (with no disjunction). The area continuity of $R h$. uniflorum is provided by this species growing in North-Eastern China (Manchuria). Rh. uniflorum, which is characterized by a wide range of morphological variability, grows in East Siberia, Mongolia, Central, North and North-East China, Primorsky and south Amursky Provinces, and the Korean Peninsula. The area of $R h$. satzyperovii is then within the area of Rh. uniflorum.

Morphometric studies on carpological character variability in $R h$. satzyperovii and $R h$. uniflorum (Basargin \& Vorobyeva, 2004), morphology and anatomy of achenes, as well as stomatographic analyses, did not reveal any specific difference (Zarembo, 2000). For all these reasons, $R h$. satzyperovii should be considered a synonym of Rh. uniflorum.

\section{Nomenclature, citations and synonyms of Rhaponticum carthamoides}

Rhaponticum carthamoides (Willd.) Iljin in Trudy Bot. Inst. Akad. Nauk S.S.S.R., Ser. 1, Fl. Sist. Vyssh. Rast. 1: 204. 1933; Soskov, Fl. URSS 28: 311. 1964; Zemlinsky, Med. plants USSR: 359. 1958. - Ic.: Polozyi, Postnicov \& Surov, Atlas areals a. resources med. pl. USSR: 185 (text, ic.), 103 (map). 1980; Zhirova, Fl. Sib. 13: 229, maps 162-164. $1997 \equiv$ Cnicus carthamoides Willd., Sp. Pl., ed. 4 [Willdenow] 3(3): 1686. $1803 \equiv$ Cnicus centauroides Willd. ex Ledeb., Fl. Ross. 2(2,7): 753. 1846 ESerratula carthamoides Poir., Encycl. (Lam.) 6(2): 561.1805 E Serratula cynarifolia Poir., Encycl. (Lam.) 6(2): 561. 1805 三Leuzea carthamoides DC. in Ann. Mus. Paris 16: 205. 1810 and Prodr. 6: 666. 1837; Ledeb., Fl. Ross. 2(2): 753. 1845-1846; Turcz., Fl. Baic.-Dahur. 2(1): 135. 1856; Kryl., Fl. West. Sibiriae 11: 2943. 1949 三 Leuzea altaica Fisch. ex Schauer, Cat. Sem. Hort. Vrat. 1834 E Cirsium carthamoides Link, Enum. pl. Hort. Berol. 2: 303. $1822 \equiv$ Halocharis carthamoides M. Bieb. ex DC., Prodr. 6: 666. 1837, pro syn. $\equiv$ Centaurea carthamoides Benth., Gen. pl. 2: 479. 1873 EStemmacantha carthamoides (Willd.) Dittrich in Candollea, 39(1): 46. 1984; Chu, Fl. Reipubl. Popul. Sin. 78(1): 185. 1987; Czerep., Sosud. rast. Rossii i sopr. gosud.: 195. 1995; Doronkin, Fl. Sib. 14: 95. 2003.

\section{Nomenclature, citations and synonyms of Rhaponticum uniflorum}

Rhaponticum uniflorum (L.) DC. in Ann. Mus. Paris 16: 189. 1810; Prodr. 6: 664. 1837; Ledeb., Fl. Ross. 2: 751. 1845-1846; Turcz., Fl. Baic.dahur. 2: 133. 1856; Franch. in Nouv. Arch. Mus. Hist. Nat. Paris 6: 62. 1883 and P1. David., 1: 183. 1884; Popov, Fl. Mid. Sib. 2: 866. 1959; Soskov, Fl. SSSR 28: 318. 1963; Vorosch., Fl. Sov. Far East: 436. 1966; Vorob., Key-book of plants Prim. and Amur.: 428. 1966; Hu in Quart. Journ. Taiwan Mus. 20 (3-4): 310. 1967; Peshkova, Fl. Central Sib. 2: 890. 1979; Kitag., Neo-Lineam. Fl. Mansh.: 666. 1979; Czerep., Vascular plants USSR: 92. 1981; Vorosch., Key-book of plants Sov. Far East: 583. 1982; Fu, Fl. Intramong. 6: 211. 1982; Vorosch., Florist. issled. v raznykh raionakh SSSR: 198. 1985; Barkalov, Vascular plants Sov. Far East 6: 314. 1992; Lee, Fl. Korea: 858. 1996; Zhirova, Fl. sib. 13: 229. 1997. - Ic.: Gmel., Fl. sib. 2: tab. 38. 1749 三 Cnicus uniflorus L., Mant. Altera.: 572. 1771; Georgi, Reise 3: 1225. 1797-1802; Willd., Sp. Pl., 3: 1685. 1804 ECentaurea monanthos Georgi, Reise 1: 231. 1775; Forbes \& Hemsl., Bot. J. Linn. Soc. 23: 470. 1888; Palib., Consp. Fl. Kor.: 120. 1898; Kom., Fl. Manchuria 3: 761. 1907; Nakai, Fl. Korea 2: 48. 1911; Kom., Fl. Sylv. Koreana 14: 107. 1923; Kom. \& Alisova, Key-book of plants of the Far-Eastern Province. 2: 1086. 1932; Chen in Bull. Mem. Inst. Biol. Bot. 5: 94. 1934; Ling in Contr. Inst. Bot. Nat. Acad. Peip. 3(4): 178. 
1935; Hu in Quart. Journ. Taiwan Mus. 19(1-2): 21. $1966 \equiv$ Centaurea grandiflora Pall., Reise 3: 237, 321. 1776; Kitag., Index Fl. Jehol.: 54. 1936 三 Centaurea membranacea Lam., Encycl. 1: 666. 1783; Hu in Quart. Journ. Taiwan Mus.19(1-2): 20. $1966 \equiv$ Serratula uniflora (L.) Spreng., Syst. Veg. 3: 388. 1826 E Leuzea dahurica Bunge, Enum. Pl. Chin. Bor. 37. 1833; Bunge id. in Mem. Acad. Sc. St. Petersb. Sav. Etrang. 2: 111. 1835 三Leuzea satzyperovii (Sosk.) Holub in Folia Geobot. Phytotax. (Praha) 8: 392. $1973 \equiv$ Leuzea uniflora (L.) Holub in Folia Geobot. Phytotax. (Praha) 8: 392. 1973; Grubov, Key-book of vascular plants of Mongolia: 262. 1982 E Rhapontica uniflora (L.) DC., Diss. Comp.: 33. 1837; Maxim., Prim. Fl. Amur.: 176. 1859; Korsh. in Acta Hort. Petrop. 12: 361. 1892; Diels in Engler in Bot. Jahrb. Beibl.: 108. 1905; Kitam. in Mem. Coll. Sci. Kyoto Univ., ser. B., 13: 30. 1937; Kitag., Lineam. Fl. Mansh.: 461. 1939; Nakai in Bull. Nat. Sc. Mus. 31: 118. 1952; T. B. Lee, Illust. Fl. Korea: 77. $1993 \equiv$ Rhaponticum dahuricum (Bunge) Turcz. in Bull. Soc. Nat. Mosc. 11: $95.1838 \equiv$ Rhaponticum monanthos (Georgi) Vorosch., Seed List State Bot. Gard. Acad. Sci. URSS viii. 28. 1953; cf. Botsch. in Not. Syst. Herb. Inst. Bot. Acad. Sci. URSS, xix. 642. 1959 $\equiv$ Rhaponticum satzyperovii Soskov in Bot. mat. Gerb. Bot. In. AN SSSR 19: 400. 1959; Soskov, Fl. SSSR 28: 317. 1963; Vorosch., Fl. Sov. Far East: 436. 1966; Czerep., Vascular plants USSR: 92. 1981; Barkalov, Vascular plants Sov. Far East 6: 314. $1992 \equiv$ Rh. uniflorum subsp. satzyperovii (Soskov) Vorosch., Key-book of plants Sov. Far East: 583. 1982; Vorosch., Florist. issled. v raznykh raionakh SSSR: $198.1985 \equiv$ Stemmacantha uniflora (L.) Dittrich in Candollea 39: 49. 1984; Chu, Fl. Reipubl. Popul. Sinicae 78, 1: 184. 1987; Czerep., Sosud. rast. Ross. sopred. gos.: 195. 1995; Doronkin, Fl. Sib. 14: 95. 2003 E Stemmacantha satzyperovii (Sosk.) Czerep., Vascular plants USSR: 195. 1995 EStemmacantha uniflora subsp. satzyperovii (Sosk.) Dittrich in Candollea 39: 49. 1984.

\section{ACKNOWLEDGEMENTS}

This research was supported by the Advice of grants of the President of the Russian Federation for support of young Russian scientists and leading scientific schools (projects MK-4620.2006.4 and 8969.2006.4) and the integration grant of the Siberian department of the Russian Academy of Sciences (06-II-SD-05-021).

\section{REFERENCES}

Adanson, M. 1763. Families des plantes 2. Vincent, Paris.

Barkalov, V. Y. 1992. The genus Rhaponticum Ludw. In: Kharkevich, S. S. (Ed.), Sosudistye rastenia Sovetskogo Dalnego Vostoka 6. Nauka, St. Petersburg: 313-315. [in Russian].

Basargin, D. \& Vorobyeva, A. 2004. Carpological studying of Far East species of genus Rhaponticum. Genetic resources of medicinal and aromatic plants. Moscow: 22-24. [in Russian].

Bentham, G. 1876. Compositae. In: Bentham, G. \& Hooker, J. D. Genera Plantarum. Lovel Reeve, London: 163-533.

Cassini, H. 1818. Aperçu des genres nouveaux, formés dans la famille des Synanthérées. Bull. Sci. Soc. Philom. Paris 1818: 73-77.

Chu, S. 1987. Stemmacantha Cass. In: Flora Republicae Popularis Sinicae 78 (1). Science Press, Beijing: 184-185.

Czerepanov, S. K. 1995. Vascular plants of Russia and adjacent states. Mir and Semiya, St. Petersburg. [in Russian].

De Candolle, A. P. 1838. Prodromus systematis naturalis regni vegetabilis 6 . Treuttel et Würtz, Paris.

Dittrich, M. 1973. Proposal to conserve the generic name Rhaponticum. Taxon 22: 314-315.

Dittrich, M. 1984. Neukombinationen in der Gattung Stemmacantha Cass. (Compositae) mit Bemerkungen zur Typisierung einiger ihrer Arten. Candollea 39: 45-49.

Doronkin, V. 2003. Dopolnenia i ispravlenia. In: Flora of Siberia 14. Nauka, Novosibirsk. [in Russian].

Greuter, W. 2003. The Euro+Med treatment of Cardueae (Compositae) - generic concepts and required new names. Willdenowia 33: 49-61.

Grubov, V. I. 1982. Key-book of vascular plants of Mongolia. Nauka, Leningrad. [in Russian].

Hill, J. 1762. The vegetable system 4. London.

Hoffmann, O. 1890. Compositae. In: Engler, A. \& Prantl, K. (Eds.). Die Natürlichen Pflanzenfamilien. Verlag. Leipzig: 87-391.

Holub, J. 1973. Contribution to taxonomy and nomenclature of Leuzea DC. and Rhaponticum auct. Folia Geobot. Phytotax. (Praha) 8: 377-395.

Holub, J. 1974. The conservation of Rhaponticum. Taxon 23: 424-425.

Jussieu, A. L. 1789. Genera Plantarum secundum ordines naturales disposita, juxta methodum in Horto regio parisiensi exaratam. Herissant and Barrois, Paris.

Kitagawa, M. 1979. Neo-Lineamenta Florae Manshuricae. Cramer, Vaduz.

Lamarck, J. B. 1779. La Flore francaise 2. Imprimerie Royale, Paris.

Ledebour, C. F. 1845. Flora Rossica. E. Schweizerbart, Stuttgart.

Lee, T. 1993. Illustrated Flora of Korea. Hyang Mun Sa, Seoul. Lee, Y. N. 1996. Flora of Korea. Kyo-Hak Publishing, Seoul. Linnaeus, C. 1753. Species plantarum. Salvii, Holmiae.

Ludwig, Ch.-G. 1747. Definitiones generum plantarum. J. F. Gleditsch, Leipzig.

Peshkova, G. A. 1979. The genus Rhaponticum Ludwig. In: Flora Tsentralnoy Sibiry 2. Nauka, Novosibirsk: 890-892. [in Russian].

Popov, M. G. 1959. The flora of Middle Siberia 2. Academy of Sciences of the USSR, Moscow and Leningrad. [in Russian]. Soskov, Y. D. 1959. To the taxonomy of the genera Rhapon- 
ticum Adans. and Leuzea DC. Bot. Mater. Gerb. Bot. AN SSSR 19: 396-408. [in Russian].

Soskov, Y. D. 1963. The genus Rhaponticum Adans. In: Shishkin, B. K. \& Bobrov, E. G. (Eds.), Flora SSSR 28. Academy of Sciences, Moscow and Leningrad: 308-322. [in Russian].

Susanna, A. \& Garcia-Jacas. N. 2007. Tribe Cardueae. In: Kadereit, J. W. \& Jeffrey, C. (Eds.), The families and genera of vascular plants 8. Springer, Berlin, Heidelberg, New York: 123-147.

Vaillant, S. 1718. Etablissement de nouveaux caractères de trois Familles ou Classes de Plantes à Fleurs composées; sçavoir, des Cynarocéphales, des Corymbifères, et des Cichoracées. Mém. Acad. Roy. Sci. 1718: 143-191.

Vorobyev, D. P., Voroschilov, V. N., Gorovoy, P. G. \& Schreter, A. I. 1966. Key-book on the plants of Primorye and
Priamurye. Nauka, Moscow and Leningrad. [in Russian]. Voroschilov, V. N. 1966. Flora of the Soviet Far East. Nauka, Moscow. [in Russian].

Voroschilov, V. N. 1982. Key-book of plants of the Soviet Far East. Nauka, Moscow. [in Russian].

Voroschilov, V. N. 1985. The list of vascular plants of the Soviet Far East. In: Floristicheskiye issledovaniya v raznykh raionakh SSSR. Nauka, Moscow: 197-198. [in Russian].

Zarembo, E. 2000. Taxonomy and resource research of Far East species of Cardueae. The dissertation author's abstract on competition of a scientific degree of Cand. Biol. Sci. Vladivostok. [in Russian].

Zhirova, O. S. 1997. The genus Rhaponticum Hill. (Leuzea DC.). In: Flora Sibiri 13. Nauka, Novosibirsk: 229-231. [in Russian]. 